\title{
1926 Yılından Günümüze İlköğretim Okullarının Programları ve Sosyal Bilgiler $^{1}$
}

\author{
Primary Schools Since 1926 Programs and Social Information \\ Mehmet Sait KORKMAZ* \\ Hatice GÜLER**
}

\begin{abstract}
$\ddot{O} z$
Cumhuriyetin kurulduğu günden bu yana eğitim programlarında bazı çalışmalar yapılmış ve bazı değişimler meydana gelmiştir. Eğitim programlarında meydana gelen bu değişimler diğer dersleri etkilediği gibi, Sosyal Bilgiler derslerini de etkilemiştir. Sosyal bilgiler alanında ders konuları, üniteler, ders saatleri ve Sosyal Bilgiler dersinin ismi ile ilgili çalışmalar yapılmıştır. Çalışma, nitel araştırma yöntemlerinden doküman incelemesi yöntemi kullanılmıştır. Araştırma boyunca, Cumhuriyetten günümüze Sosyal Bilgilerin geçmişi, oluşturulan eğitim programları ve Sosyal Bilgiler derslerinde meydana gelen değişimler üzerinde durulmuştur. 1926, 1936, 1968, 1975, 1997, 2005 ve 2012 yıllarında eğitim sisteminde yapılan değişiklikler ve sosyal bilgiler derslerine etkisi incelenmiştir. Bu yıllar boyunca müfredata getirilen Tarih, Coğrafya, Yurttaşlık Bilgisi, Hayat Bilgisi, Müsahabat-1 Ahlâkiye ve Malûmat-1 Vataniye, Toplum ve Ülke İncelemeleri, Vatandaşlık, T.C. İnkılâp Tarihi ve Atatürkçülük derslerinin amaçlarının genel olarak Sosyal Bilgiler derslerinin amaçlarını oluşturduğu tespit edilmiş. Daha önce başka isimlerle eğitim programlarında yer alan Sosyal Bilgiler dersi ilk kez 1968 yılında müfredatta yer almıștır.
\end{abstract}

Anahtar kelimler: Sosyal Bilgiler, Eğitim Programı, Ders Programı, Ders Saati.

\section{Abstract}

Since the foundation of the Republic, some studies have emerged in the education programs. These changes in education programs have affected other courses as well as Social Studies lessons. In the field of Social Studies, subjects such as course subjects, units, class hours and the name of Social Studies course have been studied. This study was carried out using the method of document analysis of qualitative research methods. Throughout the study, the history of Social Studies from the Republic to the present, the educational programs and changes in The Social Studies courses were emphasized. In 1926, 1936, 1968, 1975, 1997, 2005 and 2012, changes in the education system and its impact on social studies courses were examined. History, Geography, Dormitory Knowledge, Life Science, Community and Country Reviews, Citizenship, T.C. It is determined that the aims of the History of Revolution and Kemalism courses are the aims of social studies courses in general. The Social Studies courses, which were previously included in other education programs, were first included in the curriculum in 1968.

Keywords: Social Studies, Education Program, Timetable, Period.

\section{Giriş}

Bu çalışma, 1926 yılından günümüze eğitim programları ve sosyal bilgilerin gelişimi, sosyal bilgilerin ders saatleri ve sosyal bilgiler derslerinin müfredat değişikliği gibi konular hakkında bilgi vermektedir. $\mathrm{Bu}$ nedenle bu çalışma, konu ile ilgili inceleme yapan araştırmacılara yardımcı olmak amacıyla oluşturulmuştur

Cumhuriyetin kurulduğu günden beri eğitim programlarında çeşitli düzenlemeler yapılmıştır. Özellikle 1926 y1lı ilk mektepler programı ile cumhuriyet döneminde eğitim programları ile ilgili çalışmalar başlamıştır. Dersler, konular, ders saatleri gibi alanlarda çeşitli çalışmalar yapılmıştır.

Sosyal bilgiler dersleri de bu alanda yapılan çalışmalardan etkilenmiştir. Gerek programa sosyal bilgiler derslerinin eklenmesi, çıkarılması, gerek ders konuları ve ders saatleri gibi alanlarda yapılan değişiklikler, sosyal bilgiler dersleri ile ilgili çalışmalar yapılmasına sebep olmuştur.

\footnotetext{
${ }^{1}$ Bu makale“2005 Sosyal Bilgiler Öğretim Programı ve 2017 Sosyal Bilgiler Öğretim Programı Taslağı'nın Öğretmen Görüşlerine Göre Değerlendirilmesi (Burdur İli Örneği)” isimli tez çalışmasından üretilmiştir.

* Dr. Öğr. Üyesi, Burdur Mehmet Akif Ersoy Üniversitesi, mskorkmaz(at)mehmetakif.edu.tr.

** Arş. Gör., Ağrı İbrahim Çeçen Üniversitesi, guleer 1992@hotmail.com.
} 


\section{Yılı İlk Mekteplerin Programı ve Sosyal Bilgiler Dersleri}

Bu dönemde sosyal bilgiler dersi kapsamında hayat bilgisi, tarih, coğrafya dersleri yer almıştır. Hayat bilgisi dersinin amacı toplumla iç içe olabilmek, Türkiye Cumhuriyeti Devleti'nin önemini kavrayabilmek ve kavratabilmektir. Bu eğitimin verilmesine Türkçe, tarih ve coğrafya dersleri yardımcı olmuştur. 1926 yılı müfredat programında, öğretim yöntemleri ve öğretimde kullanılacak araç gereçler konusunda önemli kararlar alınmıştır. Bu dönemde 5. sınıfı bitiren öğrencilere Türkçe, tarih, tabiat-eşya, hesap-hendese(geometri), resim-el işi, jimnastik, musiki ve ev idaresi derslerinden sınav yapılmıştır (Ambarlı, 2010).

$\mathrm{Bu}$ dönemde ilkokul müfredatında yer alan ziraat, sağlık bilgisi, ahlâk sohbetleri ve yurttaşlık bilgisi, tarih ve coğrafya derslerinin konuları sosyal bilgiler dersinin kapsamına giren disiplinlerdir (Şahin, 2009). Buna göre, 1926 yılında yapılan değişiklikle sosyal bilgiler dersinin kapsamına ziraat, sağlık bilgisi, ahlâk sohbetleri gibi dersler de girmiştir. Bu dersler öğrencilerin sosyal hayatlarını etkileyen, onlara yaşadıkları çevre ile ilgili bilgiler veren ve sağlık konusunda bilgiler edinmelerini sağlayan dersler olarak düşünülebilir.

Tablo 1: 1926 Yılı ilkokullar için hazırlanmıș müfredat programı

\begin{tabular}{|c|c|}
\hline Öğleden Evvel Tedris Edilecek Dersler & Öğleden Sonra Tedris Edilecek Dersler \\
\hline Kurân-ı Kerim & El işleri \\
\hline Malûmatı Diniye & Ziraat \\
Mushâbat-ı Ahlâkiye & Yazı \\
Türkçe, Kıraat, Sarf ve Nahiv & Resim \\
Tarih & Musiki (Gına) \\
Hesap ve Hendese (Geometri) & Terbiye-i Bedeniyye \\
Eşya Dersleri & \\
\hline
\end{tabular}

Kaynak: Cicioğlu, 1985.

Tablo 2’de 1926 yılı ilkokullar için hazırlanmış müfredat programı yer almaktadır. Burada öğlenden önce ve öğleden sonra eğitimi verilen derslere yer verilmiştir. 1926 yıll ilkokullar için hazırlanmış müfredat programında sosyal bilgiler isminde bir ders müfredatta yoktur. Ancak öğleden sonra eğitimi verilecek dersler arasında yer alan ziraat, sağlık bilgisi, ahlâk sohbetleri ve yurttaşlık bilgisi, tarih ve coğrafya derslerinin konuları sosyal bilgiler dersinin konularını içerisine almaktadır.

1926 yılı ilkokul programı müfredatında JhonDewey'in üzerinde çalışmalar yaptığı yeni kavramlar vardır. Bu programda, "Hayat Bilgisi, Toplu Tedris, İş Okulu" kavramlarına yer verilmiştir. $\mathrm{Bu}$ yeni program ile öğrencinin gelişim sürecine de dikkat edilmiştir (Cicioğlu, 1985). Buna göre, JhonDewey'in yaptı̆̆ çalışmalarla öğrencilerin gelişimlerine ve yaşadıkları sosyal çevreye dikkat edildiği görülebilir.

2. Meşrutiyet döneminde "Tebadan Vatana Geçiş" adlı projede kıymete değer bir şekilde yer alan "Mulamat-1 Medine" dersinin adı değiştirilmişstir. Bu dersin adı"Malumat-1 Vataniye" olarak düzenlenmiştir. 1926 yılında ilkokul müfredatlarında bu dersin adı ise "Yurt Bilgisi” olarak yer almıştır (Öztürk, 2011).

O dönemde yurt bilgisi dersi köy çocukları için büyük önem arz etmiştir. Bu dersin amacı; çocuklara disiplinli bir eğitim vermek ve onları toplumun bir parçası haline getirebilmektir. 1926 yılında uygulanan eğitim programında yurt bilgisi dersinin yanında,tarih ve coğrafya dersleri 4. ve 5. sınıflara haftada ikişer saat olarak eklenmiştir (Öztürk, 2011). Buna göre, yurt bilgisi derslerinin özellikle köylerde yaşayan öğrencileri hayata hazırladığı, öğrenciler okullarda teorik olarak bilgileri öğrenirken evlerinde bunları uyguladıkları düşünülebilir. 
Tablo 2: 1926 Y1lı İkinci İlkokul Programı

\begin{tabular}{|l|c|c|c|c|c|}
\hline \multirow{2}{*}{ Dersler } & \multicolumn{3}{|c|}{ 1. Devre } & \multicolumn{2}{c|}{ 2. Devre } \\
\cline { 2 - 6 } & 1. Sınıf & 2. Sınıf & 3. Sınıf & 4. Sınıf & 5. Sınıf \\
\hline Hürkçe & 10 & 10 & 10 & 8 & 8 \\
\hline $\begin{array}{l}\text { Hesap-Hendese } \\
\text { Geometri) }\end{array}$ & 4 & 4 & 4 & - & - \\
\hline Tarih & 4 & 4 & 5 & 5 & 5 \\
\hline Coğrafya & - & - & - & 2 & 2 \\
\hline Tabiat Dersleri & - & - & - & 2 & 2 \\
\hline Eşya Dersleri & - & - & - & 2 & 2 \\
\hline Yurt Bilgisi & - & - & - & - & 2 \\
\hline Resim-Elişi & - & - & - & 2 & 1 \\
\hline Musiki & 4 & 4 & 4 & 2 & 2 \\
\hline Jimnastik & 2 & 2 & 1 & 1 & 1 \\
\hline YEKÛ́ & 2 & 2 & 2 & 2 & 1 \\
\hline (Ev İdaresi) & $\mathbf{2 6}$ & $\mathbf{2 6}$ & $\mathbf{2 6}$ & $\mathbf{2 6}$ & $\mathbf{2 6}$ \\
\hline (Dikiş) & - & - & - & $(1)$ & $(1)$ \\
\hline
\end{tabular}

Kaynak: Cicioğlu, 1985.

Tablo 3'de 1926 yılı ikinci ilkokul programı yer almaktadır. Tabloda görüldügü gibi sosyal bilgiler derslerinin konuları ilkokulun 1. devresinde hayat bilgisi dersleri olarak verilmiştir. Hayat bilgisi dersleri 1, 2 ve 3 . sınıflar için haftada 4 saat olarak programda belirlenmiştir. İlkokulun 2. devresinde ise sosyal bilgiler dersleri tarih, coğrafya ve yurttaşlık bilgisi dersleri kapsamında yer almıştır. Tarih ve coğrafya derslerinin 4 ve 5 . sınıfta 2 saat olarak eğitimi verilmektedir. Yurt bilgisi dersinin ise 4. sinıflarda 2 saat, 5. siniflarda 1 saat olarak verilmesi planlanmıştır.

\section{0 İlkokul Programı ve Sosyal Bilgiler Dersleri}

1930 yılı ilkokul programında sosyal bilgiler isminde bir ders müfredata konulmamıştır. Bunun yerine sosyal bilgiler derslerinin içeriğini oluşturan tarih, coğrafya ve yurttaşlık bilgisi disiplinlerine rastlanmaktadır (Ambarlı, 2010).

Tarih derslerinde ilk insanlığın doğuşu, yaşayışı ve sosyal hayatları ile ilgili konular, İlk Türk devletleri ve yaşadıkları yerler öğrencilere okutulmuştur (Ambarl1, 2010).Coğrafya derslerinde öğrencilere Türkiye'nin coğrafi konumu, yaşadıkları çevre, denizler, kıtalar, göller, dağlar, ovalar gibi yeryüzü şekilleri öğretilmiştir. Coğrafya derslerinin anlatımında haritalar, atlaslar, küreler, resimler, kartpostallar ve diğer coğrafi değere sahip bazı eşyalar, materyal olarak kullanılmıştır (Ambarlı, 2010).

Buna göre tarih, coğrafya ve yurttaşlık bilgisi dersleri ile ilgili konular öğrencilere okutulurken materyal kullanımına özen gösterilmiştir. Coğrafya derslerinde harita, küre vb. gibi eşyalar kullanılmıştır. Bu nedenle, bu derslerde kullanılan araç ve gereçler dersin anlatımını kolaylaştıran somut eşyalar olabilir.

\section{6 İlkokul Programı ve Sosyal Bilgiler Dersleri}

Cumhuriyet döneminde, 1929 yılında İlk Mektepler Talimatnamesi'nde amaç; çocuklara disiplinli bir eğitim vermek ve böylece onları ulusal topluma uyumlu hale getirmektir. $\mathrm{Bu}$ nedenle vatandaşlık görevleri üzerinde durulmuş ve bir ulusun nasıl kurulabileceği ile ilgili çalışmalar yapılmıştır. 1931 yılında ortaokulların ilk üç sınıfında haftada bir saat olmak üzere yurt bilgisi dersleri yer almaya başlamıştır. Daha sonra bu ders, 1937 yılında ortaokul 1. sınıflardan kaldırılmış, 2. sınıflarda ve 3. sınıflarda haftada ikişer saat olarak okutulmaya başlanmıştır (Öztürk, 2011). 
1935 yılında tekrar bir komisyon toplanmıştır. İlk mektepler müfredat programında bazı değişiklikler yapılarak 1936 yılında "Yeni İlkokul Müfredat Programı" adı ile yürürlüğe girmiştir. $\mathrm{Bu}$ programda milli eğitimin amaçlarına ilk defa geniş ölçüde yer verilmiştir (Cicioğlu, 1985). Buna göre, yeni ilkokul müfredat programı ile programda önemli değişiklikler yapılmıştır. Programın isminin değiştirilmesinin yanı sıra bu programda ilk kez milli eğitimin amaçlarına yer verilmiştir.

1936 yılı programında ezberci eğitimden kaçmak için çalışmalar yapılmıştır. Öğrencilerin gözlem ve inceleme yaparak ulusal hedefler edinmeleri sağlanmıştır. $\mathrm{Bu}$ nedenle hayat bilgilisi dersi ve bu dersin öğretimi ile ilgili faklı öğretim ilkeleri benimsenmiştir (Fer, 2005). Buna göre, 1936 yılında verilen eğitim öğretim esnasında öğrencilerin daha aktif olduğu çeşitli öğrenme yöntemleri uygulanmaya başlandığı söylenebilir.

Tablo 3: 1936 Y1lı ilkokul programı

\begin{tabular}{|c|c|c|c|c|c|}
\hline \multirow[b]{2}{*}{ Dersler } & \multicolumn{3}{|c|}{ 1. Devre } & \multicolumn{2}{|c|}{ 2. Devre } \\
\hline & 1.Sinıf & 2.Sinif & 3.Sinıf & 4.Sinıf & 5.Sinif \\
\hline Türkçe & 10 & 7 & 7 & 6 & 6 \\
\hline Tarih & - & - & - & 2 & 2 \\
\hline Coğrafya & - & - & - & 2 & 2 \\
\hline Yurt Bilgisi & - & - & - & 2 & 1 \\
\hline Tabiat Bilgisi & - & - & - & 3 & 3 \\
\hline Aile Bilgisi & - & - & - & 2 & 2 \\
\hline Hayat Bilgisi & 5 & 6 & 7 & - & - \\
\hline Hesap-Hendese (Geometri) & 4 & 4 & 4 & 4 & 5 \\
\hline Resim-İş & 4 & 4 & 4 & 2 & 2 \\
\hline Yazı & - & 2 & 1 & 1 & 1 \\
\hline Müzik & 1 & 1 & 1 & 1 & 1 \\
\hline Jimnastik & 2 & 2 & 2 & 1 & 1 \\
\hline Toplam & 26 & 26 & 26 & 26 & 26 \\
\hline
\end{tabular}

Kaynak: Cicioğlu, 1985.

Tablo 4'de 1936 yılı ilkokul programı yer almaktadır. Tabloda görüldüğü gibi sosyal bilgiler derslerinin konuları ilkokulun 1. devresinde hayat bilgisi dersi kapsamında verilmiştir. Hayat bilgisi dersi 1. sınıflar için haftada 5 saat, 2. sınıflar için haftada 6 saat, 3. sınıflar için haftada 7 saat olarak düzenlenmiştir. İlkokulun 2. devresinde ise sosyal bilgiler dersi kapsamında tarih, coğrafya ve yurttaşlık bilgisi dersleri yer almıştır. Tarih ve coğrafya derslerinin 4 ve 5. sinıfta 2 saat olarak eğitimi verilmektedir. Yurt bilgisi dersinin ise 4. sınıflarda 2 saat, 5. sınıflarda 1 saat olarak verilmesi planlanmıştır.

\section{8 İlkokul Programı ve Sosyal Bilgiler Dersleri}

1926 yılında yapılan program değişikliği ile yurt bilgisi derslerinin yanında coğrafya ve tarih dersleri de haftada ikişer saat olarak programda yer almaya başlamıştır. 1952 yılında ise 1948 yılında hazırlanan bir taslağa göre programdaki 14 farklı ders, beş grup halinde birleştirmiş ve ders konuları çalışma alanlarına göre ayarlanmıştır. İkinci kademede "Toplum ve Ülke İncelemeleri" ile "Fen ve Tabiat Bilgileri”" başlıklı iki temel ders kabul edilmiştir. Diğer dersler "Toplum ve Ülke İncelemeleri" ile "Fen ve Tabiat Bilgileri" dersleri başlı̆g altında toplanmıştır (Baysal, 2005). Buna göre, diğer dersler başlığı altında eğitimi verilen, toplum ve ülke incelemeleri dersinin içeriğini sosyal bilgiler dersleri oluşturduğu söylenebilir.

1962 yılından önceki yıllarda, ilkokul programlarında tarih, coğrafya ve yurttaşlık bilgisi adlarıyla yer alan ve sosyal bilgiler dersleri kapsamına giren bu dersler, belirtildiği gibi 
1962 tarihli ilkokul programı taslağında “Toplum ve Ülke İncelemeleri” adı altında birleştirilmiştir (Ünal ve Ünal, 2012). 1968 tarihinde toplum ve ülke incelemeleri dersinin adı "Sosyal Bilgiler" dersi şeklinde değiştirilmiştir. Böylece sosyal bilgiler dersi ilk kez okullarda yerini almıştır (Keskin, 2012). Okulların sosyal bilgiler ders müfredatında meydana gelen değişimler, bu dönemde Amerika Birleşik Devletleri'nin sosyal bilgiler programında yapılan yenilik hareketlerinden etkilenildiğinin kanıtıdır (Günden, 1995).

$\mathrm{Bu}$ dönemde oluşturulan milli eğitim şûrasında, sosyal bilgiler derslerinin ilköğretim ve orta öğretim kurumlarında okutulması kararlaştırılmıştır. 1968 yılında 4. ve 5. sınıflarda haftada beşer saat olarak yer alacağı belirlenmiştir (Öztürk, 2011). 1968 yılında bütün ilkokulların programlarında yer almaya başlayan sosyal bilgiler dersleri 1970-1971 öğretim yılında denemek amacıyla ortaokullarda da okutulmaya başlanmıştır (Günden, 1995).

Buna göre, tarih boyunca devam eden eğitimde yenilik çalışmaları içerisinde sosyal bilgiler dersleri ilk defa 1968 y1lında müfredatta yer alamaya başlamıştır. Sosyal bilgiler dersleri ilk olarak 1968 yılında bütün ilkokulların dersleri içerisinde, 1970 ve 1971 yıllarında ise ilk defa ortaokulların dersleri içerisinde yer aldığı söylenebilir.

Tablo 4: 1968 Y1lı ilkokul programı

\begin{tabular}{|c|c|c|c|c|c|}
\hline \multirow{2}{*}{ Dersler } & \multicolumn{3}{|c|}{ 1. Devre } & \multicolumn{2}{|c|}{ 2. Devre } \\
\hline & 1. Sinif & 2. Sinıf & 3. Sinif & 4. Sinif & 5. Sinıf \\
\hline Türkçe & 10 & 10 & 10 & 6 & 6 \\
\hline Matematik & 5 & 5 & 5 & 4 & 4 \\
\hline Fen Bilgisi & - & - & - & 4 & 4 \\
\hline Sosyal Bilgiler & - & - & - & 3 & 3 \\
\hline Hayat Bilgisi & 5 & 5 & 5 & - & - \\
\hline $\begin{array}{l}\text { Din Kültürü ve Ahlak } \\
\text { Bilgisi }\end{array}$ & - & - & - & 2 & 2 \\
\hline Resim-iş & 1 & 1 & 1 & 2 & 2 \\
\hline Müzik & 1 & 1 & 1 & 1 & 1 \\
\hline Beden eğitimi & 3 & 3 & 3 & 3 & 3 \\
\hline TOPLAM & 25 & 25 & 25 & 25 & 25 \\
\hline
\end{tabular}

Kaynak: Ambarlı, 2010.

Tablo 5'de 1968 yılı ilkokul programı yer almaktadır. Tabloda görüldüğü gibi sosyal bilgiler dersi 1968 yılında ilk kez müfredatta yer almıştır. İlkokulun birinci kademesinde müfredatta yer almayan sosyal bilgiler dersleri, ilkokulun ikinci kademesinde 4 ve 5. siniflar için haftada 3 saat şeklinde yer almaya ve eğitimi verilmeye başlanmıştır.

\section{5 İlkokul Programı ve Sosyal Bilgiler Dersleri}

1975 yılında kullanılan ders programında sosyal bilgiler dersleri, haftalık 26 saate denk düşmüştür. Öğrencilerin ana dersler için ve beceri gerektiren dersler için haftalık 120 dakika, hayat bilgisi ve sosyal bilgiler derslerinde yapılan bazı eğitsel çalışmalar için haftalık 60 dakika, çalışmaların değerlendirilmesi ve sonraki günlerde yapılacakların tasarlanması için ise 200 dakika gibi bir zaman dilimi ayrılmıştır. Her dersin haftalık çalışma süreleri aynı kalmak şartıyla günlük ders sürelerinin kullanımı isteğe göre uzatılmış ya da kısaltılmıştır (Cicioğlu, 1985). Buna göre, 1975 y1lı ders programında sosyal bilgiler derslerine 26 saat olarak yer verilmiştir. Bir haftada sosyal bilgilere ayrılan ders saatinin sabit kalması şartıyla, günlük ders saatlerinin değişimi programın esnek olduğunu gösterebilir.

Tablo 5: 1975 Y1lı temel eğitimin birinci kademesi haftalık ders sayısı çizelgesi

\begin{tabular}{|l|c|c|c|c|c|}
\hline \multirow{2}{*}{ Dersler } & \multicolumn{4}{c|}{ 1. Devre } & \multicolumn{2}{c|}{ 2. Devre } \\
\cline { 2 - 6 } & 1.Sınıf & 2.Sınıf & 3.Sınıf & 4.Sinıf & 5.Sınıf \\
\hline Türkçe & 10 & 10 & 10 & 6 & 6 \\
\hline Matematik & 5 & 5 & 5 & 4 & 4 \\
\hline Fen Bilgisi & - & - & - & 4 & 4 \\
\hline
\end{tabular}




\begin{tabular}{|l|c|c|c|c|c|}
\hline Sosyal Bilgiler & - & - & - & 3 & 3 \\
\hline Hayat Bilgisi & 5 & 5 & 5 & - & - \\
\hline Resim-iş & 1 & 1 & 1 & 2 & 2 \\
\hline Müzik & 1 & 1 & 1 & - & - \\
\hline Beden & 1 & 1 & 1 & - & - \\
\hline Âhlak & - & - & - & - & - \\
\hline Din Bilgisi (isteğe bağlı) & - & - & - & - & - \\
\hline Ĕgitsel Çalışmalar & 2 & 2 & 2 & 2 & 2 \\
\hline Toplam & $\mathbf{2 5}$ & $\mathbf{2 5}$ & $\mathbf{2 5}$ & $\mathbf{2 5}$ & $\mathbf{2 5}$ \\
\hline
\end{tabular}

Kaynak: Cicioğlu, 1985.

Tablo 6' da 1975 yılı temel eğitimin birinci kademesi haftalık ders sayısı çizelgesi yer almaktadır. Tabloda görüldüğü gibi ilkokulun 1. devresinde haftalık ders çizelgesinde yer almayan sosyal bilgiler dersleri ilkokulun 2. devresinde haftalık ders çizelgesinde yer almaya devam etmiştir. 4 ve 5. sınıflar içinhaftada 3 saat olarak bir çizelge hazırlanmıştır.

\section{Yılı İlköğretim Programı ve Sosyal Bilgiler Dersleri}

8 yıllık kesintisiz eğitim çalışmaları için ilköğretim okullarının "zorunlu” ve "kesintisiz" süresinin uzatılması ve 8 yıla çıkarılması amacıyla 1973 yılında ilk çalışmalara başlanmış, konuyla ilgili çalışma gurubu oluşturulmuştur. 1981-1982 eğitim-öğretim yılında üç ilde pilot uygulamaya geçilerek 8 yıllık kesintisiz eğitim uygulaması denenmiştir. Uygulamanın olumlu sonuçlar vermesiyle birlikte 1990'dan sonra 8 y1llı eğitim çalışmalarına hız verilmiştir (Gündüz, 2011).

18 Ağustos 1997 tarihinde 23084 sayılı Resmi Gazetede yayınlanan 4306 sayılı yasa ile; "ilkokul" ile "ortaokul" ibareleri "ilköğretim okulu" olarak değiştirilmiştir. Bu yasa ile ilköğretim kurumları 8 yıla çıkarılmış, okullar 8 yıllık okullar haline getirilmiştir. $\mathrm{Bu}$ okullarda da zorunlu ve kesintisiz eğitim süreci sağlanmıştır (Resmi Gazete, 1997). Buna göre, 1997 yılında çıkarılan bir karar ile ilkokul ve ortaokullar birleştirilerek ilköğretim okulları haline getirilmiştir. Bu kararın alınmasında zorunlu eğitimin 8 yıla çıkarılmasının etkisi olduğu düşünülebilir.

1990 yılında uygulanmaya başlanan sosyal bilgiler programı, 1998 Programı’na kadar devam etmiştir. Zorunlu Eğitimin 8 yıla çıkarılmasından sonra 1998 yılında, Talim Terbiye Kurulu Başkanlığı'nın 02.04.1998 tarih ve 62 karar sayısıyla; Talim Terbiye Kurulu Başkanlığı'nın 30.05.1990; 62 ve 15.03.1993; 80 tarih ve sayılı kararlarıyla kabul edilen İlkokul 4 ve 5. Sinıf Sosyal Bilgiler Dersi Öğretim Programı'nın, 25.04.1985; 67 ve 15.03.1993; 81 tarih ve sayılı kararlarıyla kabul edilen Ortaokul Millî Tarih Programı ile 24.06.1985; 95 ve 15.03.1993; 79 tarih ve sayılı kararlarıyla kabul edilen Ortaokul Millî Coğrafya Programı'nın kaldırılarak, İlköğretim Okulu Sosyal Bilgiler Program'1 kabul edilmiştir. 02.04.1998 tarih ve 2487 sayılı Tebliğler Dergisi’nde yayınlanmıştır (Milli Eğitim Bakanlığı, 1998, s.531).

Buna göre, sosyal bilgiler dersi 1998 programına kadar yalnızca ortaokullar için okutulmuş bir ders olmuştur. Zorunlu eğitim çalışmaları ve bazı eğitimde yenileme çalışmalarının da etkisiyle sosyal bilgiler dersi alanında bir değişikliğe gidilmiştir. Alınan karar göre, 1998 y1lına kadar sadece ortaokullarda eğitimi verilen sosyal bilgiler derslerinin ilkokullarda da eğitimi verilmeye başlanmıştır.

1998 yılı öğretim programını değerlendirmek amacıyla seçkin kişiler ile bir görüşme düzenlenmiştir. Görüşmeye katılanlalar tarafından 1998 öğretim programının eksik olduğu ve bu programın geliştirilmesi gerektiği sonucuna varılmıştır (Çatak, 2015).

1968 yılından 1998 yılına kadar Hayat Bilgisi Programı uygulaması devam etmiştir Talim Terbiye Kurulu Başkanlığı'nın 03.12.1997 tarih ve 161 karar sayısıyla; Talim Terbiye Kurulu Başkanlığı'nın 01.07.1968; 171 tarih ve sayılı kararlarıyla kabul edilen İlkokul Hayat Bilgisi Programı uygulamadan kaldırılarak, 1998-1999 öğretim yılında itibaren uygulanmak üzere, İlköğretim Okulu Hayat Bilgisi 
Program'ı kabul edilmiştir. Ocak1998 tarih ve 2484 sayılı Tebliğler Dergisi’nde yayınlanmıştır(Milli Eğitim Bakanlığı, 1998a, s.5).

Buna göre, 1998 ve 1968 yılları arasında hayat bilgisi dersleri ilkokul hayat bilgisi programı olarak devam etmiştir. Ancak 1998 yılında ilkokul hayat bilgisi programı ibaresi kaldırılmıştır. Bunun yerine ilköğretim okulu hayat bilgisi programı şeklinde programda yer almiştır.

Tablo 6: 1997 Y1lı ilkokul ders programı

\begin{tabular}{|l|l|l|l|l|l|l|l|l|}
\hline \multicolumn{1}{|c|}{ Dersler } & \multicolumn{5}{c|}{ Sinıflar } \\
\cline { 2 - 8 } & $\mathbf{1}$ & $\mathbf{2}$ & $\mathbf{3}$ & $\mathbf{4}$ & $\mathbf{5}$ & $\mathbf{6}$ & $\mathbf{7}$ & $\mathbf{8}$ \\
\hline Türkçe & 2 & 12 & 12 & 6 & 6 & 5 & 5 & 5 \\
\hline Matematik & 4 & 4 & 4 & 4 & 4 & 4 & 4 & 4 \\
\hline Hayat Bilgisi & 5 & 5 & 5 & - & - & & - & - \\
\hline Fen Bilgisi & - & - & - & 3 & 3 & 3 & 3 & 3 \\
\hline Sosyal bilgiler & - & - & - & 3 & 3 & 3 & 3 & - \\
\hline Vatandaşlık ve İnsan Hakları Eğitimi & - & - & - & - & - & - & 1 & 1 \\
\hline T.C. İnklâp Tarihi ve Atatürkçülük & - & - & - & - & - & - & - & 2 \\
\hline Yabancı Dil & - & - & - & 2 & 2 & 4 & 4 & 4 \\
\hline Din Kültürü ve Ahlâk Bilgisi & - & - & - & 2 & 2 & 2 & 2 & 2 \\
\hline Resim-iş & 2 & 2 & 2 & 1 & 1 & 1 & 1 & 1 \\
\hline Müzik & 2 & 2 & 2 & 1 & 1 & 1 & 1 & 1 \\
\hline Beden Eğitimi & 2 & 2 & 2 & 2 & 2 & 1 & 1 & 1 \\
\hline İş Eğitimi & - & - & - & 3 & 3 & 3 & 3 & 3 \\
\hline Trafik ve İlk Yardım Eğitimi & - & - & - & - & - & - & - & 1 \\
\hline Bireysel ve Toplu Etkinlik & 3 & 3 & 3 & - & - & - & - & - \\
\hline Seçmeli Dersler & - & - & - & 3 & 3 & 2 & 2 & 2 \\
\hline Toplam & $\mathbf{3 0}$ & $\mathbf{3 0}$ & $\mathbf{3 0}$ & $\mathbf{3 0}$ & $\mathbf{3 0}$ & $\mathbf{3 0}$ & $\mathbf{3 0}$ & $\mathbf{3 0}$ \\
\hline
\end{tabular}

Kaynak: Çatak, 2015.

Tablo 7'de 1997 yılı haftalık ders çizelgesi yer almaktadır. Bu tablo zorunlu eğitim süresinin 8 yıla çıkarılmasından sonra yayımlanmıştır. Burada sosyal bilgiler dersleri 4, 5, 6 ve 7. sınıflar için haftada üçer saat olarak düzenlenmiştir. Sosyal bilgiler dersinin kapsamına giren hayat bilgisi dersi 1,2 ve 3 . sınıflara haftada beşer saat, vatandaşlık ve insan hakları eğitimi dersi 7 ve 8. sinıflara haftada birer saat, inkılâp tarihi ve Atatürkçülük dersi 8. sinıflara haftada ikişer saat olarak verilmeye başlanmıştır.

\section{Yılı İlköğretim Programı ve Sosyal Bilgiler Dersleri}

2004-2005 yılı eğitim programında yapılan değişiklik ile davranışçı eğitim anlayışından oluşturmacı eğitim anlayışına geçilmiştir. 2004-2005 eğitim öğretim yılında bazı pilot illerde yapılandırmacı eğitim programı uygulanmaya başlanmıştır. 2005-2006 eğitim öğretim yılında ise pilot uygulamanın olumlu sonuçlar vermesiyle ülkenin her yerinde yer alan ilköğretim okullarında yapılandırmacı eğitime geçilmiştir (Keskin, 2012).

2006-2007 öğretim yılından sonra 6 ve 7. sınıfların sosyal bilgiler programında da yapılandırmacı eğitim uygulanmıştır. Bu yeni sosyal bilgiler programını eski programdan ayıran özellikler vardır. Bu programın en önemli özelliği, eski programda yer alan davranışçı anlayışın terk edilmiş olması ve yapılandırmacı öğrenme ilkesinin benimsenmiş olmasıdır (Bilgili, 2010). Buna göre, yapılandırmacı eğitim ile birlikte öğrencilerin derse katılımına daha çok dikkat edileceği, dersi öğrencilerin şekillendireceği söylenebilir.

Tüm ilköğretim programlarını kapsayacak şekilde hazırlanan bu yapılandırmacı eğitim programın hedefleri aşağıdaki gibidir.

Dünyadaki bilimsel ve teknolojik gelişmeler ve bunun Türkiye'ye yansımaları

$\checkmark$ Eğitim bilimlerindeki öğrenme öğretme anlayışındaki gelişme 
Eğitimde kalite ve eşitliği yükseltme ihtiyacı

$\checkmark$ Ekonomiye ve demokrasiye duyarlı bir eğitim gereksinimi

$\checkmark$ Ferdi ve milli değerlerin küresel değerler içinde geliştirilmesi

$\checkmark 8$ yıllık temel eğitim için program bütünlüğünün sağlanması

$\checkmark$ Her bir dersin kendi içinde kavramsal bütünlük sağlama gerekliliği sayılabilir(Çatak, 2015, s.28).

Buna göre yapılandırmacı eğitim öğrencilere verilen eğitimin kalitesini artırmayı amaç edinmiştir. Yapılandırmacı eğitim öğrencilere sağlanan eğitimde firsat ve imkân eşitliğini artırmayı hedeflemektedir. Hem toplumun hemde öğrencilerin beklenti ve ihtiyaçları göz önünde bulundurularak yaparak yaşayan, yaşayarak öğrenen bireyler yetiştirilmesini istemektedir.

Yapılandırmacı eğitimle sosyal bilgiler ders kitaplarında klasik anlatımdan ziyade en çok kullanılan öğretim yöntemi örnek olay incelemesi olmuştur. Örnek olay incelemesi yöntemi, öğrenciye bir durum hakkında bilgi sahibi olma ve tartışma yapabilme becerisi sağlamaktadır. Bu programın amacı öğrencileri gerçek hayatta karşılaşabilecekleri olaylar ile ilgili önceden deneyim sahibi yapmaktır (Kabapınar, 2009).

Yapılandırmacı eğitimle beraber ölçme ve değerlendirmede kullanılan yöntemler diğer öğretim programlarından farklıdır. Yapılandırmacı öğretim modelinde süreç odaklı bir ölçme ve değerlendirme anlayışı benimsenmiştir. Diğer öğretim programlarında ise sonuç odaklı ölçme ve değerlendirme anlayışı benimsenmiştir (Bilgili, 2010).Yapılandırmacı eğitim, sosyal bilgiler öğretim programında öğrenciler için gerekli bilgi, beceri ve tutumları ortaya çıkarmıştır. Her öğrenci için gerekli içerikler tanımlanmıştır. Öğretmenler sınıflarda uygulanması gereken etkinlikler ile ilgili çeşitli alıştırma çalışmaları yapmışlardır (Yurdabakan, 2011). Buna göre, yapılandırmacı eğitim öğrenciyi merkeze alarak öğrencinin en iyi şartlarda ve deneyerek öğrenmesini amaç edinmiştir. Bu nedenle sadece yapılan sınav sonuçlarının öğrencinin bilgilerini değerlendirmede yeterli olmadığg görüşünü savunduğu düşünülebilir.

Tablo 7: 2005 Yılı ilköğretim programı haftalık ders dağıtım çizelgesi

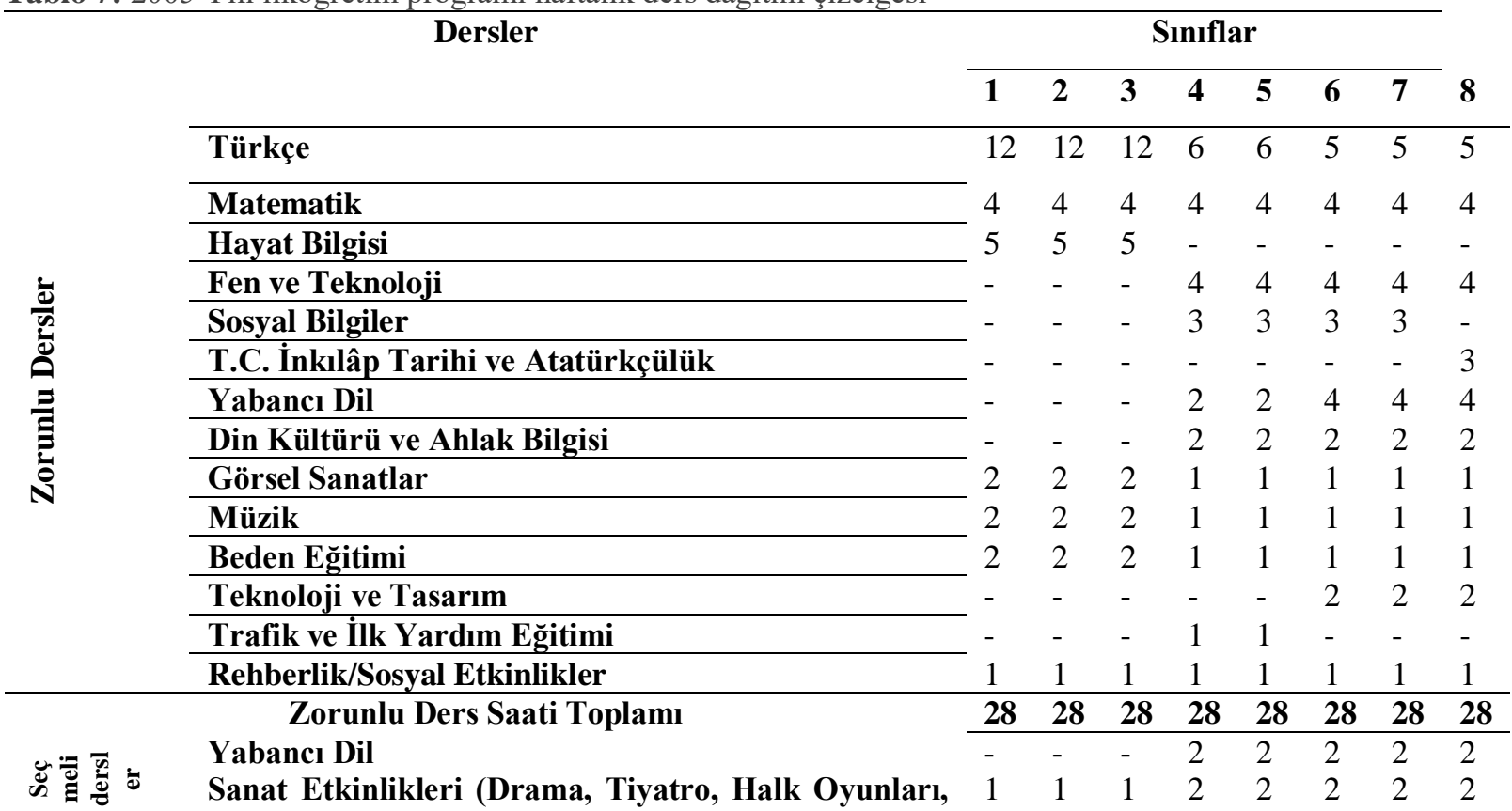




\begin{tabular}{|c|c|c|c|c|c|c|c|c|c|c|}
\hline \multicolumn{11}{|c|}{ Enstrüman, Resim, Fotoğrafçılık, Heykel vb.) } \\
\hline & $\begin{array}{l}\text { Spor Etkinlikleri (Güreş, Futbol, } \\
\text { Voleybol, Masa T. Vb.) }\end{array}$ & Basketbol, & 1 & 1 & 1 & 2 & 2 & 2 & 2 & 2 \\
\hline & Bilgisayar & & 1 & 1 & 1 & 1 & 1 & 1 & 1 & 1 \\
\hline & Satranç & & 1 & 1 & 1 & 1 & 1 & 1 & 1 & 1 \\
\hline & Düşünme Eğitimi & & - & - & - & - & - & 1 & 1 & 1 \\
\hline & Halk Kültürü & & - & - & - & - & - & 1 & 1 & 1 \\
\hline & Tarım/Hayvancılık Uygulamaları & & - & - & - & - & - & 1 & 1 & 1 \\
\hline & Takviye ve Etüt Çalışmaları & & 1 & 1 & 1 & - & - & - & - & - \\
\hline Seçmeli ders & saati toplamı & & 2 & 2 & 2 & 4 & 4 & 2 & 2 & 2 \\
\hline Genel toplam & & & 30 & 30 & 30 & 30 & 30 & 30 & 30 & 30 \\
\hline
\end{tabular}

Kaynak: Milli Eğitim Bakanlığı, 2005.

Tablo 8'de 2005 yılı ilköğretim programı haftalık ders dağıtım çizelgesi yer almaktadır. Bu tablo zorunlu ve seçmeli dersler ve bu derslerin hangi sınıflarda kaç saat eğitimi verileceğini göstermektedir. Sosyal bilgiler dersleri burada zorunlu dersler arasında yer almaktadır. 4, 5, 6 ve 7. sınıflar için sosyal bilgiler dersleri zorunlu ders olarak belirlenmiştir. Bu sınıflar için sosyal bilgilerin haftalık ders saati 3 saat olarak bildirilmiştir.

\section{Yıllık Zorunlu Eğitim ve Sosyal Bilgiler Dersleri (2012)}

Türkiye'de eğitim sisteminin $4+4+4$ şeklinde kademelere ayrılması ve zorunlu eğitim süresinin 12 yıla çıkarılması ilk kez 18. Eğitim şurasının toplanması ile gündeme gelmiştir. 20 Şubat 2012 tarihinde bir grup başkanvekilleri ve bazı vekiller bu öneriyi meclise sunmuştur. 11 Mart 2012 tarihinde yasa meclisten geçmiş ve 11 Nisan 2012 tarihinde resmi gazetede yayımlanmıştır (Gür, Özoğlu, Çoşkun ve Görmez, 2012).

2012 yılında Türkiye'deki eğitim sisteminde kapsamlı yenilikler yaşanmıştır. 18.Milli Eğitim Şurası'nda alınan karar şöyledir:"Zorunlu eğitim öğrencilerin yaş grupları ve bireysel farklılıkları göz önünde bulundurularak; 1 yıl okul öncesi eğitim, 4 yıl temel eğitim, 4 yıl yönlendirme ve ortaöğretime hazırlık eğitimi ve 4 yıl ortaöğretim olmak üzere öğrencilere farklı ortamlarda eğitim almaya fırsat verecek şekilde 13 yıl olarak düzenlenmelidir" (Milli Eğitim Bakanlığı, 2012).

Buna göre, en son 1997 yılında zorunlu eğitim süresi ile ilgili yapılan çalışmalardan sonra, bu konu ile ilgili ilk defa 2012 yılında bir düzenleme yapılması isteği gündeme gelmiştir. 1997 yılında 5+3 şeklinde düzenlenen ve sekiz yıllık zorunlu eğitim şeklinde ifade edilen eğitim süresi, 2012 yılında $4+4+4$ şeklinde ve on iki yıllık zorunlu eğitim olarak değiştirilmiştir. Böylece okul öncesi eğitim, temel eğitim, yönlendirme eğitim ve ortaöğretime hazırlık eğitimi ve ortaöğretim olarak kademelere isimler verilmiştir.

“MADDE 1 - 5.1.1961 tarihli ve 222 sayılı İlköğretim ve Eğitim Kanununun 3 üncü maddesi aşağıdaki şekilde değiştirilmiştir.

MADDE 3 - Mecburi ilköğretim çağı 6-13 yaş grubundaki çocukları kapsar. Bu çağ çocuğun 5 yaşını bitirdiği yılın eylül ayı sonunda başlar, 13 yaşını bitirip 14 yaşına girdiği yılın öğretim yılı sonunda biter.”

"MADDE 2 - 222 sayılı Kanunun yedinci maddesi aşağıdaki şekilde değiştirilmiştir.

MADDE 7 - İlköğretim; birinci maddede belirtilen amacı gerçekleştirmek için kurulmuş dört yıl süreli ve zorunlu ilkokul ile dört yıl süreli ve zorunlu ortaokuldan oluşan bir Milli Eğitim ve Öğretim Kurumudur."

“MADDE 3 - 222 sayılı Kanunun dokuzuncu maddesinin birinci fikrası aşağıdaki şekilde değiştirilmiştir.

"MADDE 9 - 1739 sayılı Kanunun 25 inci maddesinin mülga birinci fikrası aşağıdaki şekilde yeniden düzenlenmiştir. İlköğretim kurumları; dört yıl süreli ve zorunlu ilkokullar ile dört yıl süreli, zorunlu ve farklı programlar arasında tercihe imkân veren ortaokullar ile imam-hatip ortaokullarından oluşur. Ortaokullar ile imam-hatip ortaokullarında lise eğitimini destekleyecek şekilde öğrencilerin yetenek, gelişim ve tercihlerine göre seçimlik dersler oluşturulur. Ortaokul ve liselerde, Kur'an-1 Kerim ve Hz. Peygamberimizin hayatı, isteğe bağlı seçmeli ders olarak okutulur. Bu okullarda okutulacak diğer seçmeli 
dersler ile imam-hatip ortaokulları ve diğer ortaokullar için oluşturulacak program seçenekleri Bakanlıkça belirlenir."

“MADDE 10 - 1739 sayılı Kanunun 26 ncı maddesi aşağıdaki şekilde değiştirilmiştir.

"MADDE 26 - Ortaöğretim, ilköğretime dayalı, dört y1llık zorunlu, örgün veya yaygın öğrenim veren genel, mesleki ve teknik öğretim kurumlarının tümünü kapsar. Bu okulları bitirenlere ortaöğretim diploması verilir."

"MADDE 11 - 1739 sayılı Kanuna aşağıdaki geçici madde eklenmiştir.

GEÇİCI MADDE 3 - Zorunlu ortaöğretim 2012-2013 eğitim-öğretim yılından itibaren uygulanmaya başlanır. Bakanlar Kurulu uygulamayı bir eğitim- öğretim yılı ertelemeye yetkilidir.”

"MADDE 13 - 16.8.1997 tarihli ve 4306 sayılı Kanunun geçici 1 inci maddesinin (A) fikrasının (2) numaralı bendinin (c) alt bendinde yer alan 'sekiz yıllık kesintisiz ilköğretim' ibaresi 'ilköğretim ve ortaöğretim' şeklinde değiştirilmiş ve maddede yer alan 'sekiz yıllık kesintisiz' ibareleri madde metninden çıkarılmıştır” (Resmi Gazete, 2012).

Buna göre, mecburi eğitimle ilgili olarak 6 yaşından itibaren başladığı, 13 yaşın sonunda son bulduğu ifade edilmiştir. 12 yıllık zorunlu eğitim, sınıfları $4+4+4$ şeklinde kademelere ayırmıştır. İlk 4 yıllık süre ilkokulun birinci kademesinden, ikinci 4 yıllık süre ilkokulun ikinci kademesinden ve üçüncü 4 yıllık süre ise öğrencinin genel eğitim ve ya mesleki ve teknik eğitim alacağı kademeden oluşmaktadır. Burada birinci kademede dersin işlenişi çoğunlukla sınıf öğretmenlerine ait iken ikinci ve üçüncü kademede dersin işlenişi branş öğretmenlerine ait olduğu ifade edilmiştir.

Tablo 8: 2010-2011Y1lı ilköğretim programı haftalık ders dağıtım çizelgesi

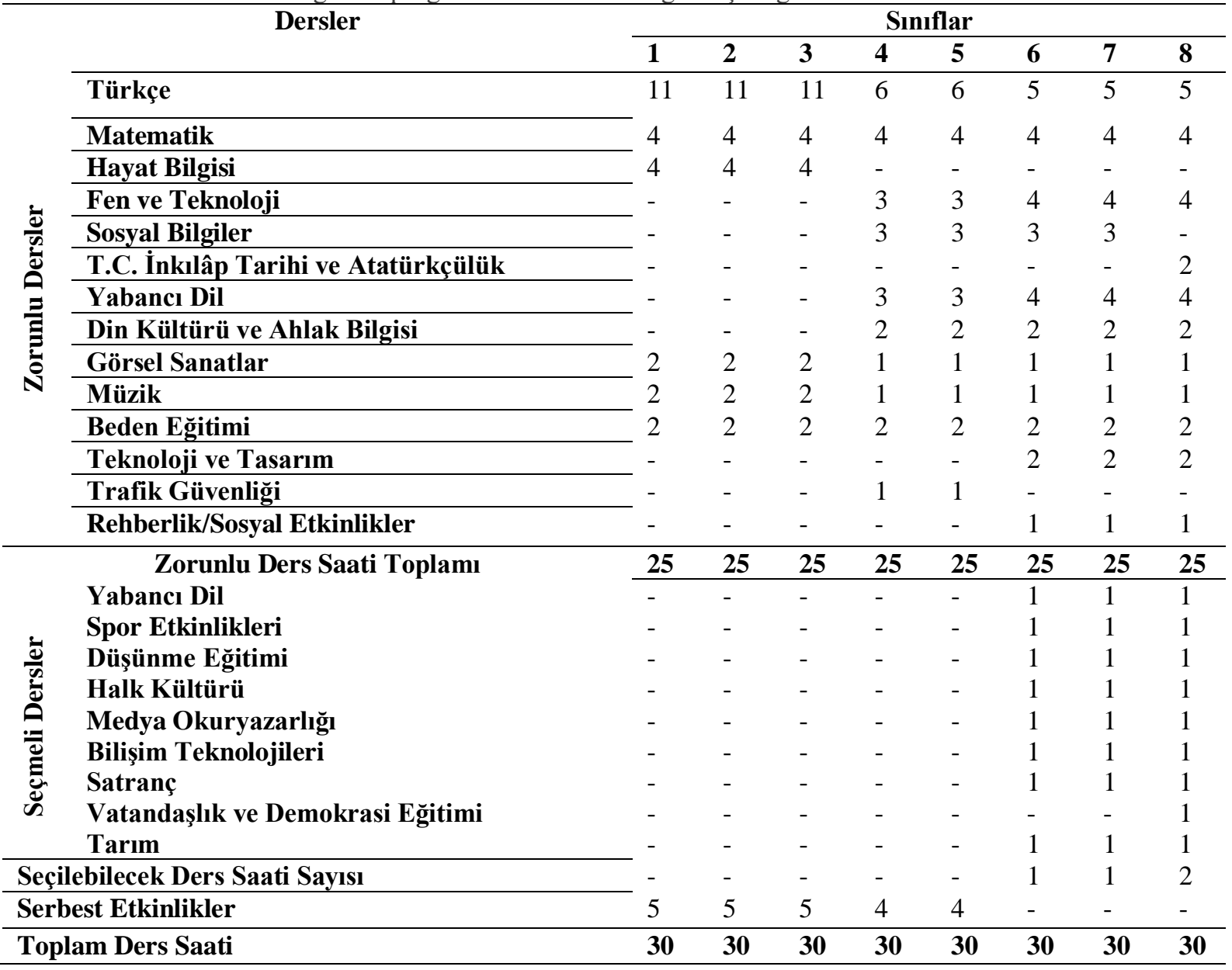

Kaynak: Milli Eğitim Bakanlığg, 2010. 
Tablo 9'da 2010-2011 yılı ilköğretim programı haftalık ders dağıtım çizelgesi yer almaktadır. Tabloda görüldüğü gibi, bu dönemde sosyal bilgiler dersi, 2005 yılı haftalık ders çizelgesini gösteren eski program ile aynı kalmıştır. Ders saatleri, ders süreleri ve dersin işlenişi alanında herhangi bir değişiklik yapılmamıştır. Ancak "Vatandaşlık ve Demokrasi Eğitimi, Medya Okuryazarlığı” gibi 2005 yılı haftalık ders çizelgesinde yer almayan ve sosyal bilgiler kapsamına da giren seçmeli derslerin haftada 1 saat olarak eğitimi verilmesi planlanmıştır.

\section{Sonuç}

Cumhuriyet öncesi ve sonrası Türk eğitim sistemi incelendiğinde, eğitim programlarında yapılan değişiklikler dikkat çekmektedir. Özellikle cumhuriyet kurulduktan sonra eğitim programlarında sık sık değişiklik yapılmıştır. Ders programı, ders saati, dersin ismi ve zorunlu eğitim yılı ile ilgili çeşitli düzenlemeler yapılmıştır.

Araştırmanın amacı doğrultusunda eğitim programları ve sosyal bilgilerin gelişimi, sosyal bilgilerin ders saatleri ve sosyal bilgiler derslerinin müfredat değişikliği gibi konularda incelemeler yapılmıştır. Araştırma sonucunda elde edilen verilere bulgular bölümünde yer verilmişstir.

Türkiye'de 1926, 1936, 1968, 1975, 1997, 2005 ve 2012 y1llarında eğitim sistemleri ile ilgili yapılan çalışmalardan, genel olarak sosyal bilgiler dersleri de etkilenmiştir. 1926 y1lında ilkokullarda sosyal bilgilerin kapsamında hayat bilgisi ve malumat-1 vataniye dersi okutulmuştur. Daha sonra malumat-1 vataniye dersinin ismi "Yurt Bilgisi" olarak değiştirilmiştir. Sonraki yıllarda yapılan çalışmalarla yurt bilgisi dersi ise "Yurttaşlık Bilgisi" olarak değiştirilmiştir. 1936 yılında bu derslerin haftalık saatleri artırılmıştır. 1962 yılında yapılan eğitim çalışmalarıyla tarih, coğrafya ve yurttaşlık bilgisi dersleri "Toplum ve Ülke İncelemeleri" adı altında birleştirilmiştir. 1968 yılında yapılan bir diğer eğitim çalışmasıyla toplum ve ülke incelemeleri dersinin ismi "Sosyal Bilgiler" olarak değiştirilmiştir. Böylece sosyal bilgiler ismi ilk kez 1968 yılında yapılan eğitim çalışmalarıyla müfredatta yer almıştır. 2005 yılında eğitim sistemimizde baştan aşağı meydana gelen değişiklik sosyal bilgiler dersini de etkilemiştir. Bu dönemde davranışçı eğitim anlayışından yapılandırmacı eğitim anlayışına geçilmiştir. Artık öğrencinin merkeze alındığı oluşturmacı bir eğitim yaklaşımı uygulanmaya başlanmıştır. 2012 yılında 4+4+4 zorunlu eğitim anlayışı sosyal bilgiler derslerinde herhangi bir değişiklik yaratmamışken vatandaşlık ve demokrasi eğitimi dersinin saatlerini azaltmıştır. Medya okuryazarlığ1, halk kültürü, hukuk ve adalet, düşünme eğitimi gibi sosyal bilgiler dersini içerik olarak kapsayan seçmeli dersler müfredata getirilmiştir.

\section{Kaynakça}

Ambarl1, A. (2010). Türkiye'de cumhuriyetten günümüze sosyal bilgiler programları (değişiklikler, düzenlemeler, güncellemeler), (Yüksek Lisans Tezi). Selçuk Üniversitesi. Eğitim Bilimleri Enstitüsü, Konya.

Baysal, Z. N. (2005). Hayat bilgisi ve sosyal bilgiler programlarinın felsefi temelleri. İstanbul: Lisans Yayıncılık.

Bilgili, A. S. (2014). Sosyal bilgilerin temelleri. Ankara: Pegem Akademi.

Cicioğlu, H. (1985). Türkiye cumhuriyetinde ilk ve ortaöğretim (Tarihi Gelişimi). Ankara: Ankara Üniversitesi Basımevi.

Çatak, M. (2014). Ortaokullarda sosyal bilgiler öğretiminin öğretmen görüşlerine göre incelenmesi, (Doktora Tezi). Afyon Kocatepe Üniversitesi. Sosyal Bilimler Enstitüsü, Afyon. 
Çatak, M. (2015). Türkiye'de sosyal bilgiler eğitim programlarının incelenmesi, EKEV Akademi Dergisi, 19(62), 69-94.

Fer, S. (2005). 1923 yllından günümüze Cumhuriyet dönemi ilkögretim programları üzerine bir inceleme. Cumhuriyet Dönemi Eğitim Politikaları Sempozyumu, Marmara Üniversitesi Atatürk Eğitim Fakültesi ve Başbakanlık Atatürk Kültür, Dil Ve Tarih Yüksek Kurumu Atatürk Araştırma Merkezi. İstanbul.

Gündüz, M. (2011), Zorunlu ve kesintisiz eğitimin kısa tarihi, Eğitime Bakış Dergisi, (21), 310.

Günden, S. (1995). Sosyal bilgiler öğretimine genel bir bakış. İlkögretim Okullarında Sosyal Bilgiler Ögrretimi ve Sorunları. Ankara: T.E.D. Öğretim Dizisi, 13.

Gür, B. S., Özoğlu, M., Coşkun, İ. ve Görmez, M. (2012). 2012'de Eğitim. 12 Ocak 2014.http://file.setav.org/Files/Pdf/20130104114533_seta_analiz_2012egitim.pdf

Kabapınar, Y. (2009). Illkögretimde hayat bilgisi ve sosyal bilgiler ögretimi. Ankara: Maya Akademi.

Keskin, Y. (2012). Türkiye'de 1970'li yıllardan günümüze kadar yayınlanmış ilkokul, ortaokul ve ilköğretim okulu programlarında yer alan tarih dersi konularının dönemlere göre incelenmesi. International Online Journal of EducationalSciences, 2012, 4(2), 442-461.

Milli Eğitim Bakanlığı (1974). Tebliğler dergisi IX. Şûra Özel Sayısı, 37 (1788).

Milli Ĕgitim Bakanlığı (1998a). Tebliğler dergisi, 61 (2484).

Milli Eğitim Bakanlığı (2005). Tebliğler dergisi, 68 (2575).

Milli Eğitim Bakanlığ (2010). Tebliğler dergisi, 73 (2637).

Resmi Gazete, (1997). T.C. Resmi Gazete, 18 Ağustos, (23084).

Resmi Gazete, (2012). T.C. Resmi Gazete, 11 Nisan, (28261).

Öztürk, C. (2011). Sosyal Bilgiler Öğretimi. Ankara: Pegem Akademi.

Şahin, M. (2009). Cumhuriyetin kuruluşunda günümüze Türkiye'de hayat bilgisi programlarının gelişimi. Uluslararası Sosyal Araştırmalar Dergisi. 2(8), 402-410.

Şimşek, U., Küçük, B. ve Topkaya, Y. (2012), Cumhuriyet dönemi eğitim politikalarının ideolojik temelleri, International Periodical For The Languages, Literature and History of Turkish or Turkic Volume 7/4, Fall 2012, 2809-2823.

Ünal, F. ve Ünal, M. (2012). Sosyal bilgiler öğretim programları (1924-2005) ve ders kitaplarında (2005-2010) harita okuma becerisi. Milli Ĕgitim Dergisi, Sayl. 174, 165183.

Yaşar, Ş. (2005). Sosyal bilgiler programı ve ögretimi. ĕgitimde yansımalar: VIII yeni ilköğretim programlarını değerlendirme sempozyumu bildiriler kitabı içinde (s.329342) Ankara: Sim Matbaas1.

Yıldırım, A. ve Şimşek, H. (2013). Sosyal bilimlerde araştırma yöntemleri. Ankara: Seçkin Yayıncilik.

Yurdabakan, İ. (2011). Yapılandırmacı kuramın değerlendirmeye bakışı: eğitimde alternatif değerlendirme yöntemleri. Ankara Üniversitesi Eğitim Bilimleri Fakültesi Dergisi, 44(1), 51-77. 